\title{
THE DEVELOPMENT OF TEACHING SKILLS TO SUPPORT ACTIVE LEARNING IN UNIVERSITY SCIENCE (ALIUS)
}

\author{
Danny R. Bedgood, Jr \\ Agricultural \& Wine Sciences \\ Charles Sturt University, Australia \\ dbedgood@csu.edu.au \\ Adam J Bridgeman \\ School of Chemistry \\ The University of Sydney, Australia \\ a.bridgeman@chem.usyd.edu.au \\ Mark Buntine, Mauro Mocerino, \\ Daniel Southam \\ Department of Chemistry, \\ Curtin University, Australia \\ m.buntine@curtin.edu.au. \\ m.mocerino@curtin.edu.au, \\ d.southam@curtin.edu.au \\ Kieran F Lim \\ School of Biological and Chemical \\ Sciences, Deakin University, Australia \\ lim@deakin.edu.au
}

\author{
Michael Gardiner, Brian Yates \\ School of Chemistry, University of \\ Tasmania, Australia \\ michael.gardiner@utas.edu.au, \\ brian.yates@utas.edu.au
}

Gayle Morris

Faculty of Science and Technology, Deakin University, Australia gayle.morris@deakin.edu.au

Simon M. Pyke

School of Chemistry and Physics, The

University of Adelaide, Australia simon.pyke@adelaide.edu.au

\begin{abstract}
This paper describes an Australian Learning and Teaching Council funded project for which Learning Design is encompassed in the broadest sense. ALIUS (Active Learning In University Science) takes the design of learning back to the learning experiences created for students. ALIUS is not about designing a particular activity, or subject, or course, but rather the development of a method, or process, by which we have re-designed the way in which learning occurs in large university classrooms world wide.
\end{abstract}

Keywords

active learning, learning leaders, student-centred, university science

education

\section{Introduction}

First year science programs in Australian Universities are characterised by large enrolments, sometimes well over 1,000 students per subject. Current teaching strategies tend to combine administrative "coping" such as dividing large cohorts into large, sequential and repeated lectures to sometimes 500 students with teaching that often privileges didactic methods; that is, teaching that is teacher-centred and based on uni-directional, transmission modes of learning. While such methods are widespread in university Chemistry classes, research shows that student-centred teaching methods lead to improved student outcomes (Johnson \& Johnson, 1989). Within the academic science teaching community, there is a growing desire to shift from highly teachercentred practice to modes of supporting learning that are more student-centred. There are ad hoc 
examples of individual science lecturers who experiment and achieve change, for example, in establishing student-directed learning in the context of large lectures, or in exploring the affordances of blended learning. However, without a coordinated effort, it remains unclear how to distill and harness local pedagogical experimentation into useful knowledge that might broadly influence Australian higher education science learning and teaching (L\&T). Learning leadership is needed, yet it remains unclear how leadership might form the basis for systemic change that "takes hold sustainably and consistently in daily practice" (Scott, Coates, \& Anderson, 2008, p. vii).

The calls from international groups for changes to more student-centred teaching echo a growing evidence-base from the scholarship of teaching and learning literature. For example, the American Chemical Society (ACS) Committee on Professional Training (2008) reported:

Programs have the opportunity to design innovative curricula that meet the needs and interests of their particular students by defining degree tracks or concentrations requiring specified indepth course work. The curriculum must also include experiences that develop student skills essential for their effective performance as scientific professionals. (p. 8)

Elsewhere, the ACS also noted that:

Solving scientific problems often involves multidisciplinary teams. The ability to work in such teams is essential for a well-educated scientist. Students should be able to work effectively in a group to solve scientific problems, be effective leaders as well as effective team members, and interact productively with a diverse group of peers. Programs should incorporate team experiences in classroom and laboratory components of the Chemistry curriculum.

(American Chemical Society (ACS) Committee on Professional Training, 2008, p. 15)

Further to this, the European Commission Directorate General for Research (Rocard, 2007) recommended (as its Recommendation 2):

Improvements in science education should be brought about through new forms of pedagogy: the introduction of inquiry-based approaches in schools ....and the development of teachers' networks should be actively promoted and supported. (p. 3)

Similarly, the International Council of Associations for Science Education and the Australian Science Teachers Association (2008) have released a declaration for action calling for a change to the way science is taught to focus on interactive-based approaches in the classroom.

Why such international groups are pushing for changing to a more student-centred teaching method warrants questioning. A number of improved learning outcomes have been reported, included those of Johnson and Johnson (1989) who suggested the following:

i. higher achievement and increased retention

ii. increase in higher-level reasoning, deeper-level understanding, and critical thinking

iii. increased time on task and less disruptive behaviour

iv. greater achievement motivation and intrinsic motivation to learn

v. greater ability to view situations from others' perspectives and greater social support

vi. improve positive attitudes toward subject areas, learning, and school

vii. more positive self-esteem based on basic self-acceptance

viii. greater social competencies.

Students have also indicated they value a more student-centred learning approach to teaching. Some of the authors of this paper have surveyed their students. Feedback from commencing science students at University of Adelaide (2007 First Year Expectation survey) indicated that $83 \%$ of respondents $(n=378)$ agreed or strongly agreed that working with other students in class time will be important to their learning. At Charles Sturt University, $78 \%$ of first year Veterinary Science students $(n=42)$ agreed and/or strongly agreed that Process Oriented Guided Inquiry Learning (POGIL) student-centred class activities (to be explained later in this paper) encourage them to study more efficiently. These exemplify the strong interest students have in learning in a social environment. 
Despite the fact these learning techniques have been well known and documented for decades, they have rarely appeared in Chemistry classes until recently. The authors of this paper were not taught in this way and it seems few students are being taught this way now. Few colleagues use these methods beyond an occasional application in class; many still mostly lecture. This is not a problem just in Australia - Bedgood (in Adlong, et al., 2006) found such student-centred techniques were rarely used among colleagues at three major Universities in the US. The authors of this paper are from tertiary institutions spread around Australia and can testify to a similar situation at Australian universities.

A survey conducted in March 2008 (unpublished) by Bedgood asked every university Chemistry instructor in Australia (over 400 individuals) about their satisfaction with their teaching style and other aspects of their teaching practice; 45 individuals (11\%) responded from 29 different universities. Respondents were asked if they agreed with the statements listed in Table 1 to a great extent, to a lesser extent, or to a small extent. Responses from the survey include:

Table 1. Results from surveying 400 Chemistry teaching academics $(n=45)$

\begin{tabular}{lc}
\hline \multicolumn{1}{c}{ Question } & $\begin{array}{c}\text { agree to a lesser or } \\
\text { small extent }\end{array}$ \\
\hline I am satisfied with my teaching style & $43 \%$ \\
I am familiar with cooperative or collaborative learning methods & $73 \%$ \\
My students are engaged during class & $66 \%$ \\
I am satisfied with student achievement in class & $69 \%$ \\
There is often discussion among students during my class & $83 \%$ \\
I think students learn well in a lecture format & $91 \%$ \\
\hline
\end{tabular}

These data suggest that almost half of Australian University Chemistry instructors are less than satisfied with their teaching style; only $25 \%$ are familiar with student-centred cooperative or collaborative teaching methods, $66 \%$ report low student engagement, and $69 \%$ are less than satisfied with student achievement in their classes. The majority of respondents, $81 \%$, indicated they spend more than $75 \%$ of class time lecturing, even though less than $10 \%$ of respondents thought that students learn well in a lecture format. This survey suggests that among university Chemistry instructors, there is a perceived need for a change in teaching practice. The RACI Future of Chemistry Report (2005) indicated a considerable shortage of university-educated chemists in Australia, as well as a lower-than-needed number of students studying Chemistry and Science in general. By examining the benefits of student-centred teaching methods, in order to improve classroom teaching, it may be possible to not only impact Chemistry student retention and graduation rates, but to have application across all science disciplines. In this way, the dire shortage of students studying Chemistry, and science in general, in high school and university might be improved. The current project will provide evidence to support the changing of teaching methods in other science disciplines suffering from the same shortages of interested students and competent employees; many other science disciplines have very large student numbers in their first year subjects as well. Results of this project can inform studies in other disciplines. One of the investigators on this project, Professor Marjan Zadnik, is a leading physics educator who will aid in the dissemination to the physics teaching community.

In summary, the literature and international industry/academic/government groups indicates a need for more student-centred teaching practice, university instructors believe a change in teaching practice could improve student learning, and students themselves indicate they believe team learning with fellow students will be important to their learning.

\section{Methods}

ALIUS (Active Learning in University Science) is a teacher-focussed leadership initiative to build student-centred teaching capacity in university academics. Three domains were identified as the 
framework upon which sustainable learning and teaching (L\&T) innovation could be built. These domains are described in Table 2. The process through which this will occur is as follows:

1. project leaders, as the first group of Science Learning Leaders, will undergo training:

a. practice-based training which will lead to L\&T innovation in their own classrooms, and

b. leadership training which will equip them to foster and develop colleagues at their University to a change in classroom practices.

2. project leaders will serve as Science Learning Leaders for innovation in their colleagues' classrooms.

3. project leaders will disseminate L\&T innovation and Learning Leadership to nearby universities by:

a. practice-based training that will lead to L\&T innovation in classrooms at neighbouring universities, and.

b. leadership training that will develop a new group of Science Learning Leaders at neighbouring universities to promote and systematise a change in classroom practices.

Table 2: Three domains for sustainable L\&T innovation

\begin{tabular}{|c|c|c|}
\hline Domains & Development Strategy & Purpose \\
\hline $\begin{array}{l}\text { Learning } \\
\text { Leaders }\end{array}$ & $\begin{array}{l}\text { Learning Leaders will be developed in the } \\
\text { following programs: } \\
\text { 1. Leadership Development Program, } \\
\text { 2. Practice Based Innovation Training. }\end{array}$ & $\begin{array}{l}\text { To develop leadership capacity in } \\
\text { the project leaders to equip them } \\
\text { with skills to lead change first at } \\
\text { their institutions, followed by } \\
\text { developing leaders and leading } \\
\text { change at other local institutions. }\end{array}$ \\
\hline $\begin{array}{l}\text { Practice- } \\
\text { Based L\&T } \\
\text { Innovation }\end{array}$ & $\begin{array}{l}\text { Learning Leaders at each of the } \\
\text { collaborating Universities will develop } \\
\text { practice-based innovation in L\&T. }\end{array}$ & $\begin{array}{l}\text { To improve student learning, } \\
\text { engagement, retention, and } \\
\text { performance in large Chemistry } \\
\text { classes through increased use of } \\
\text { student-centred teaching practice. }\end{array}$ \\
\hline Learning Hub & $\begin{array}{l}\text { The Learning Hub will provide a virtual } \\
\text { space within which the developing } \\
\text { community of Science Learning Leaders } \\
\text { will engage with each other, share }\end{array}$ & $\begin{array}{l}\text { Serve as local and national } \\
\text { clearinghouse for development of } \\
\text { institutional Learning Leaders and } \\
\text { dissemination of L\&T innovation. }\end{array}$ \\
\hline
\end{tabular}
innovative strategies, mentor each other, and create a materials archive.

Project leaders were recruited through two criteria:

1. Geographical distribution, and,

2. Knowledge, interest and participation in Chemical Education Research.

Leaders at universities in Melbourne, Sydney, Hobart, Adelaide, Perth, and Wagga Wagga were identified; the geographic distribution was important to the project so that, over time, supportive communties of practice could develop among academics at nearby institutions. Initially comprising of eight academics (seven Chemistry and one Physics), as word spread of the project, several more people became involved - additional Chemistry academics at Hobart and Perth, and an educational designer at Deakin. Prior experience of the project leader (Adlong et al., 2006) has demonstrated that participation of individuals from diverse disciplines and backgrounds can make valuable contributions to the discussion and reflection on teaching practice. Inclusion of physics as another science discipline was intended to explore the transferability of the developed methods of ALIUS to science disciplines besides Chemistry. 
The project leaders at the six universities have met twice a year in Melbourne, Perth, Sydney, and Adelaide. At these meetings, the leaders underwent Learning Leadership Training and PracticeBased Innovation Training, facilitated by recognised experts. Ethics approval was obtained from the lead university (Charles Sturt University) to meet requirements at all participating institutions.

\section{Research settings}

At Deakin University, a common first year level Chemistry program is taught across two campuses. Prior to 2010, one of the authors, Kieran Lim, was based at the Geelong campus, teaching Level-1 classes of approximately 170 students Semester 1) and 120 students (Semester 2). Approximately 40 of these students indicated their intention to major in Chemistry, while most of the remainder were enrolled in biology, biomedical science and other science disciplines. In 2010, Dr Lim, transferred to the Burwood campus which has approximately 370 (Semester 1) and 320 (Semester 2) Level-1 Chemistry students. Despite the larger numbers, fewer (less than 20) students intend to major in Chemistry, with the remainder split across Biology, Biomedical science, Health sciences, Food science and Education.

The School of Chemistry in Hobart at the University of Tasmania teaches to around 250 students at first year level in the main program that leads to further options for study at higher levels. This large group includes around 20 students who will major in Chemistry and a further 100 whose degree enrolment either requires some second year Chemistry or they opt out at this stage in the BSc program as they specialise in a 4-4-2 based degree structure. The whole year program involves six staff delivering equal length topics. The lectures are given in a traditional tiered lecture theatre and four repeat tutorials are offered in a flat bus seat style seminar room.

Around 2,300 students at The University of Sydney take first year Chemistry units each year. These are divided according to prior knowledge and degree specialisations so that lecture classes have around 200 students and tutorial classes have around 25 students. The students are drawn from every faculty of the university, including professional degrees.

At Curtin University there are three Chemistry and one physics staff involved in applying studentcentred learning approaches to their teaching. One of the Chemistry staff, Daniel Southam, was not part of the original project team, but became involved after attending the workshop and seminar at the Royal Australian Chemical Institute (RACI) Chemical Education Conference in December 2008. Student-centred learning approaches have been introduced into three first year Chemistry courses, Chemistry 101 and 102 (each $370 \mathrm{chem} /$ nanotech/chem eng/extract metal students), and Introduction to Pharmaceutical Chemistry 121 ( 160 pharmacy). The approach from each academic has been different, although all have adopted a blended learning approach (some mix of mini-lecture/group activities/clicker questions). In conjunction with the classes in Perth, another staff member in Malaysia has begun to apply active methods in class. Another lecturer teaching biomedical science and nutrition students ( 150 students) has begun implementing the group activity worksheets into her tutorial program. Dr Southam has also implemented group activity worksheets into his second year Chemistry classes.

Charles Sturt University is the largest provider of tertiary distance education in Australia Approximately 1,300 students take first year Chemistry, choosing from a single semester Fundamental Chemistry class ( 220 students), or the larger two semesters of general Chemistry (CHM1A 650 students, CHM1B 400). Approximately 1/3 of the students study by distance; the internal classes are taught in a single large lecture of up to 200 students.

Around 700 students at the University of Adelaide take first year Chemistry each year (the two courses on offer are streamed based upon prior knowledge). Of these, around 50 students will ultimately become Chemistry majors. A significant proportion of the remaining students are required to take Chemistry at first year level (and in many cases second year level) due to their degree program requirements. Teaching is predominantly by lectures which are given in a traditional tiered theatre. 


\section{Developing learning leadership at six universities}

It is well known that initiating change in teaching practice is extremely difficult (Diamond, 2006; McManus, 2002; Stigler \& Hiebert, 2004). It is difficult to change one's own practice, but very difficult to extrinsically motivate change in teaching practices of others. The Science Learning Leaders used a method of appreciative inquiry (Cooperrider \& Srivastva, 1987) to examine their own teaching practice, reasons that have motivated them to change their practice, fears and concerns about implementing changes in their teaching practice, and barriers to implementing the changes they desire. The outcomes of the exercise allow the Science Learning Leaders to develop materials and resources to use as exemplars to lead change in teaching practice among colleagues. These discussions will be approached as a social encounter in which knowledge is collaboratively constructed and not just a means of 'mining' the existing knowledge of the respondents (Gubrium \& Holstein, 1999; Fontana \& Frey, 2000). Discussions are designed to be a site for transformation of lecturer perceptions, and hence teaching practice (Adlong et al., 2006).

The eight Science Learning Leaders developed their leadership skills over two stages. Stage 1 involved professional development (PD) in leadership capabilities in addition to PD to develop new skills in student-centred teaching. During this stage, the learning leaders developed Learning Leadership Action Plans for their institution.

The leadership PD occurred through workshops and seminars provided by university support staff, in consultation with the project leaders to focus on development of Leaders of Change in L\&T. This PD was a collaborative exploration between the PD provider and the Learning Leader participants. As the Learning Leaders progressed in their experience and development, additional leadership development workshops were held to build participants' leadership skills. This process of developing Learning Leaders was evaluated through discussions using action research (Kemmis \& McTaggart, 2000) and appreciative enquiry methods in order to devise a PD program which can be shared with colleagues at other universities, and disseminated by university L\&T Centres.

Stage 2 provided advanced training in student-centred teaching methods and an opportunity to refine and re-develop Learning Leadership Action Plans.

The PD in L\&T Innovation - student-centred instruction - was provided by facilitators not only experienced in student-centred teaching practice in their own Chemistry classes, but also experienced in facilitating workshops modelling student-centred teaching practices for university Chemistry instructors. The framework used in this project is POGIL - Process Oriented Guided Inquiry Learning - an NSF funded project attracting over US\$3 million since 2001. The POGIL project (www.pogil.org) has funded the development of student-centred activities and materials for high school and first through fourth year University Chemistry classes in the USA. In addition to development and assessment of learning materials for student-centred teaching, another vital component of the POGIL project is dissemination of student-centred teaching methods through nationwide introductory and advanced workshops; these workshops involve experienced Chemistry instructor/facilitators leading discussions of and modelling student-centred instruction methods. POGIL facilitators create a student-centred learning environment to model practice in the classroom, allowing participants to experience the approach from a student's perspective; participants are introduced to various instructional techniques that support a student-centred learning environment. Workshops are tailored to the interests and needs of the attendees - like implementing such methods in large classrooms. It is these experienced POGIL facilitators who have provided the PD in L\&T Innovation in Australia - Suzanne Ruder of Virginia Commonwealth University, Rick Moog of Franklin \& Marshall College, Jennifer Lewis of the University of South Florida, Vicki Minderhout of Seattle University, and Renee Cole of the University of Central Missouri.

While there are many ways of implementing student-centred learning, the POGIL facilitation was chosen for this project because of strong positive feedback from Australian and New Zealand Chemistry instructors who attended a POGIL workshop at the RACI/NZIC/NZASE Chemical 
Education Conference in 2007. These Chemistry instructors were overwhelmingly positive about the POGIL model as a method to improve teaching in their classes. University participants were surveyed about the workshop by DB: all participants either strongly agreed or agreed they: 'would like to use POGIL type methods in my classes.' Based upon the feedback of these Australian and New Zealand participants, the POGIL teaching method appeared to serve as a concrete example of a student-centred teaching method. Every participant commented on the desire for more training and supervised practice to implement the teaching method. It is because of the overwhelmingly positive feedback from Australian university Chemistry instructors, the practiced experience in using student-centred teaching methods in their classes, and their experience in facilitating workshops disseminating such teaching methods, that this ALTC project used POGIL workshops for the PD in L\&T Innovation.

The intention of this project has created a group of Australian Science Learning Leaders experienced in L\&T innovation in their subjects, and experienced in leading others to changes in teaching practice. It was anticipated that at the end of this project there would be minimal need in the future for POGIL facilitators to come from the U.S due to the building of capacity in Australia.

Dissemination of the development of Science Learning Leaders is occurring towards the end of this two year project, where the Learning Leaders - the project leaders -share the leadership development experiences developed in the project with colleagues at neighbouring universities and at national conferences and workshops. In this way, by the end of 2010, the project will have begun the development of a systemic change in university Chemistry and also, hopefully, teaching in other science disciplines.

Completion of this project will see the formation of a group of Science Learning Leaders experienced in using student-centred teaching methods, experienced in workshops building Leaders of Change, and experienced in workshops facilitating changes in teaching practice. In this way, the project will create an Australian-centred group to build Learning Leadership and foster systemic change in teaching practice.

\section{Developing practice-based innovation at six universities}

Practice-based innovation trials were conducted at six institutions, using approaches developed through Learning Leadership Action Plans. The trials were implemented by Science Learning Leaders at their own institutions, supported by the national group of Science Learning Leaders through the Science Learning Hub.

Expanded trials of innovative teaching practice took place during the second half of 2009 and all of 2010 within the Faculties where the Learning Leaders do their teaching. By the end of 2010, all institutions involved in this project will have established Science Learning Leaders, and will have implemented trial innovation in science L\&T in large first year lectures.

Dissemination of project resources and methods has begun through Learning Leaders' activities with colleagues, conference presentations and workshops (such as the RACI Chemical Education Conference December 2008), Uniserve-Science (2009, 2010), Connect 2010, the RACI National Convention (2010), the HERDSA conference (2010), and the IUPAC 2010 International Conference on Chemical Education and will culminate towards the end of 2010 through workshops and peer modelling of student-centred teaching by project leaders with colleagues at neighbouring universities.

The Science Learning Leaders promote research-informed practice by:

- Developing materials for Australian Chemistry classes to encourage L\&T innovation in first year university science teaching

- Training Learning Leaders to identify the characteristics of innovative science teaching 
- $\quad$ Revising and redesigning POGIL workshops fostering student-centred learning to meet Australian classroom culture

- Providing local initiatives like presentations, workshops, and peer modelling for local institutions, including university based L\&T processes

\section{Creating the Science Learning Hub}

The Science Learning Hub (www.alius.edu.au) was developed to:

- $\quad$ support the network of activities of the Science Learning Leaders by acting as a clearinghouse for experiences in changing their teaching practice and fostering change in practice of their colleagues.

- encourage national, regional and local dissemination of evidence-based practices in leading innovation in science teaching through workshops and seminars .

- provide training to science teachers through developed workshops, seminars, and peer modelling of teaching practice .

- foster regional membership of Science Learning Hub by offering support and encouragement to instructors engaged in changing their teaching practice.

- build active multidisciplinary networks of science educators among science disciplines outside Chemistry

- $\quad$ encourage public discourse in science L\&T innovation through developed seminar and workshops.

The Science Learning Hub was created by a website developer in consultation with the project leaders, Project Manager, and interested colleagues. The project leaders and team members developed a menu of anticipated needs and functionalities.

A summary of the ALIUS approach is shown in Figure 1.

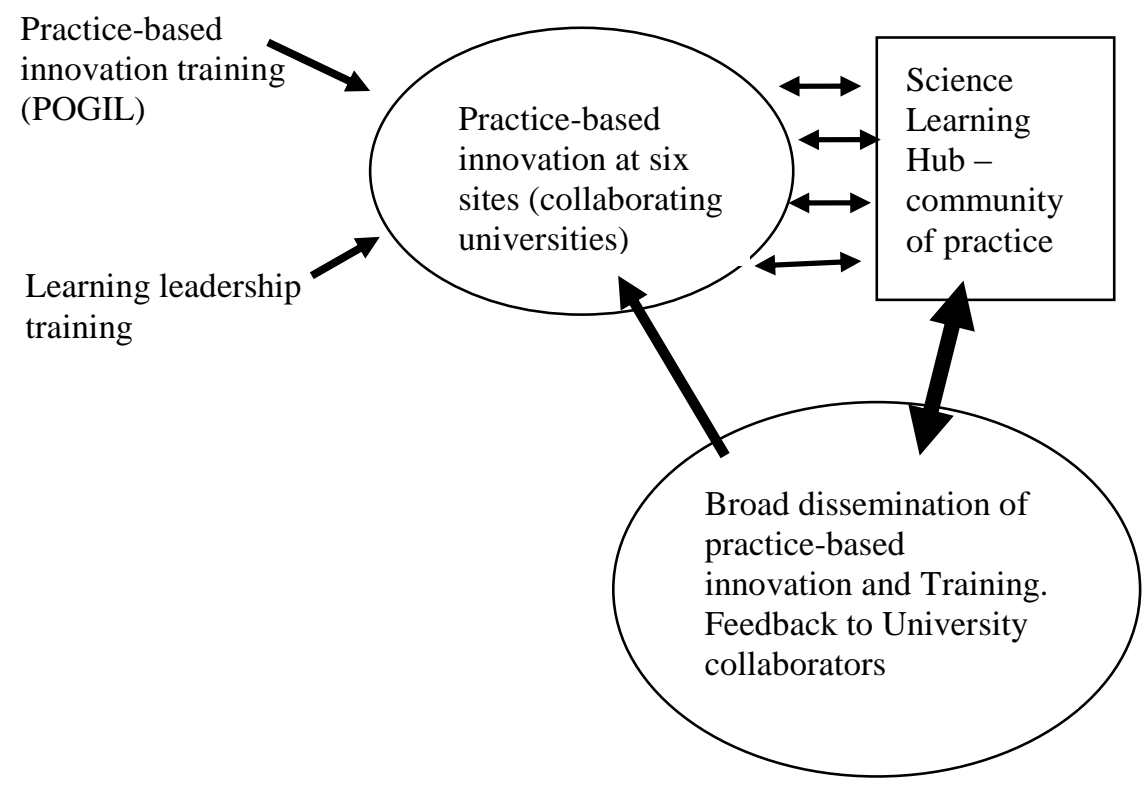

Figure 1: The ALIUS approach 


\section{A Generic Approach}

As the funding for this project comes to a close, we continue to reflect upon a number of questions: How do academics learn new ways to teach, and what is the best way to support their learning? To what extent do academics reflect on their teaching practice, and discover new and different ways to help our students learn? How do we lead colleagues to carefully critique their teaching? How do we Lead Learning Development in our teaching, and in our colleagues teaching?

We believe the methods used in this project can serve as a model for other projects that seek to develop learning. Regular face-to-face meetings proved vital to accomplish goals, but also to build the network connections - the community - between project leaders. It was uniformly enriching to intentionally dedicate the time to spend several days thinking about our teaching and our teaching practice.

Publication limitations require that the analysis and results for ALIUS will be reported in another paper. We can, however, put forward some suggestions on how to build a Learning Leadership team:

- meet regularly face to face;

- commit to devoting time for meeting, professional development, and trialling and evaluation of innovations in teaching;

- include members with different backgrounds or disciplines; and,

- allow for variety in implementations.

\section{References}

Adlong, W., Bedgood, D., Bishop, A., Dillon, K., Prenzler, P., Robards, K., \& Ryan, D. (2006). Reaching outside of the discipline: Chemistry teachers or organisational developers? In A. Bunker \& I. Vardi (Eds.). Critical Visions: Thinking, Learning and Researching in Higher Education. Proceedings of the 29th Annual HERDSA Conference. Rotorua, 1-4 July 2006 (pp. 19-27). Retrieved May 15, 2009 from http://www.herdsa.org.au/?page_id=164

American Chemical Society Committee on Professional Training. (2008, Spring). Undergraduate professional education in Chemistry: ACS guidelines and evaluation procedures for bachelor's degree programs. Washington, DC: American Chemical Society. Retrieved September 28, 2010, from http://portal.acs.org/portal/fileFetch/C/WPCP.../pdf/WPCP_008491.pdf

Cooperrider, D., \& Srivastva, S. (1987). Appreciative inquiry in organizational life. In R. Woodman \& W. Pasmore (Eds.), Research in Organizational Change and Development, 1 (pp. 129-169). Greenwich, CT: Jai Press.

Diamond, R.M. (2006). Why colleges are so hard to change. Retrieved September 8, 2006, from http://www.insidehighered.com/views/2006/09/08/diamond

Fontana, A., \& Frey, J. (2000). The interview: From structured questions to negotiated text. In N. Denzin \& Y. Lincoln (Eds.), Handbook of qualitative research $\left(2^{\text {nd }}\right.$ ed), (pp. 645-672). London: Sage.

Gubrium, J.F., \& Holstein, J.A. (1999). At the border of narrative and ethnography. Journal of Contemporary Ethnography, 28(5), 561-573.

International Council of Associations for Science Education and the Australian Science Teachers Association (2008, July 16). The Australian, Higher Education Supplement, p. 3.

Johnson, D.W., \& Johnson, R. (1989). Cooperation and competition: Theory and research. Edina, $\mathrm{MN}$ : Interaction Book Company.

Kemmis, S., \& McTaggart, R. (2000). Participatory action research. In N. Denzin \& Y. Lincoln (Eds.), Handbook of qualitative research (2 ${ }^{\text {nd }}$ ed.), (pp. 567-605). London: Sage.

McManus, D. (2002). How do we change the way we teach? CIDR Teaching and Learning Bulletin, 5(4). 
Rocard, M. (2007). Science education now: A renewed pedagogy for the future of Europe.

European Communities. Luxembourg: Office for Official Publications of the European Communities.

Royal Australian Chemical Institute (RACI). (2005). Future of Chemistry study: Supply and demand of chemists. Retrieved September 21, 2010, from http://www.raci.org.au/national/downloads/Future\%20of\%20Chemistry\%20Report.pdf

Scott, G., Coates, H., \& Anderson, M. (2008). Learning leadership in times of change: Academic Leadership capabilities for Australian higher education. Sydney, Australia: Australian Learning and Teaching Council/University of Western Sydney.

Stigler, J., \& Hiebert, J. (2004). Improving mathematics teaching. Educational Leadership, 61(5), $12-17$.

\section{Acknowledgements}

The authors thank the Australian Learning and Teaching Council (ALTC) for an ALTC Grant and the POGIL Project (USA) for in-kind support. The support of the Australian Council of the Deans of Science, the Royal Australian Chemical Institute, and each of our Universities is acknowledged. The authors thank members of the POGIL team, Rick Moog, Suzanne Ruder, Jennifer Lewis, Vicky Minderhout, and Renee Cole for their help and assistance. Professor Craig McInnes and Professor Colin Mason who helped the ALIUS team in developing leadership skills are also acknowledged.

Copyright (C) 2010 Danny Bedgood, Adam Bridgeman, Mark Buntine, Kieran Lim, Michael Gardiner, Mauro Mocerino, Gayle Morris, Simon Pyke, Daniel Southam, Brian Yates, and Marjan Zadnik 